\title{
Interactive comment on "Deep convective influence on the UTLS composition in the Asian Monsoon Anticyclone region: 2017 StratoClim campaign results" by Silvia Bucci et al.
}

\section{Anonymous Referee \#1}

Received and published: 5 February 2020

Based on the StratoClim aircraft observation and back-trajectory modelling, this manuscript investigated the convective injection of trace gases into the UTLS within the Asian monsoon anticyclone. The convective sources in the air parcel samples were diagnosed by integrating the trajectories output with high-resolution observations of cloud tops from geostationary satellites. The larger influence by convective injections was found from the continental sources of China and India for all the 8 flights during the campaign over Nepalese and Northern Indian region. Observed thin filamentary structures of higher $\mathrm{CO}$ air were mostly associated with young convective air and a predominant South-China origin. These results will enhance understanding the transport of surface pollutants to the stratosphere during the Asian monsoon region. I

Printer-friendly version

Discussion paper 
recommend its publication in ACP before two major issues are resolved.

Major issues:

1. In this manuscript, the convective source is identified when the trajectory is found with a pressure higher than the high cloud top pressure, and the highest and opaque cloud classes are representative of the deep convective events. The features of cloud top height will determine how the convective contribution changes with height, as discussed in the later part of this manuscript. So whether the cloud top heights of these highest and opaque cloud classes can represent the deep convective main outflow levels is a critical issue. I'm wondering the uncertainty in this issue. The manuscript should have some detailed description about the uncertainty.

2. The convective sources diagnosed in this manuscript are based on the StratoClim flight tracks, which only cover a small part of the Asian monsoon anticyclone, and to the south of the anticyclone center. Whether the convective sources diagnosed here are different from other regions and can represent the whole anticyclone is a critical issue, which should be considered with caution. The manuscript should discuss this issue.

Minor issues:

1. Page 2 Line 7: This statement is valid in the upper troposphere and lower stratosphere.

2. Page 2-3: These papers (Chen et al., 2012; Bergman et al., 2013; Vogel et al., 2015) have different targeted parcels (within the AMA or not) and therefore different sources, which should be noted.

3. Page 3 Line 8: In situ balloon soundings over the Tibet Plateau by Bian et al. (GRL, 2012) could be mentioned here.

4. Page 6 Lines 19-30: The comparison among EAD, EAZ, EID and EIZ is also done by Li et al. (ACPD, 2019), which could be cited here.

Interactive

comment

Printer-friendly version

Discussion paper

C2 
5. Page 7 Line 5-6: The plume is located at \#6 at 34000s UTC?

6. Page 9 Line 5: F6 therefore sampled the inner part of the AMA. Whether the parcels sampled during F6 are called "inner part" depend how the inner part of the AMA is defined. The $100 \mathrm{hPa}$ circulation is centered around 33N, while the flight track position is 20-26 N, where is 7-13 degrees from the center. China sources make a critical contribution to the south part of AMA, which has also been shown by Yan \& Bian (AAS, 2015).

7. Page 9 Line 6: The cold point pressure is derived from ERA5?

8. Page 9 Line 7-8: flight. The mean winds around the flight position were purely Easterlies, transporting air from the center of South China along the anticyclonic circulation, which is also the main reason why South China contributes a lot in the convective sources as discussed in Page 7. This issue should be mentioned there.

9. Page 9 Line 11-12: I'm curious if there were no aircraft dive here, would the CO peak be observed?

\section{Refrences:}

Bian, J. C., Pan, L. L., Paulik, L., Vömel, H., and Chen, H. B.: In situ water vapor and ozone measurements in Lhasa and Kunming during the Asian summer monsoon, Geophys. Res. Lett., 39, L19808, doi:10.1029/2012GL052996, 2012.

Li, D., Vogel, B., Müller, R., Bian, J., Günther, G., Plöger, F., Li, Q., Zhang, J., Bai, Z., Vömel, H., and Riese, M.: Dehydration and low ozone in the tropopause layer over the Asian monsoon caused by tropical cyclones: Lagrangian transport calculations using ERA-Interim and ERA5 reanalysis data, Atmos. Chem. Phys. Discuss., https://doi.org/10.5194/acp-2019-816, in review, 2019

Yan, R. and J. Bian, 2015: Tracing the boundary layer sources of carbon monoxide in the Asian summer monsoon anticyclone using WRF-Chem, Adv. Atmos. Sci., 32, 943-951, doi:10.1007/s00376-014-4130-3, 2015. 
Interactive comment on Atmos. Chem. Phys. Discuss., https://doi.org/10.5194/acp-2019-1053, 2020.

\section{ACPD}

Interactive comment 